SHORT COMMUNICATION

\title{
Molecular evidence of Babesia infections in Spinose ear tick, Otobius megnini infesting stabled horses in Nuwara Eliya racecourse: A case study
}

\author{
G.C.P. Diyes ${ }^{1,2}$, R.P.V.J. Rajapakse ${ }^{3}$ and R.S. Rajakaruna ${ }^{1,2, *}$ \\ ${ }^{1}$ Department of Zoology, Faculty of Science, University of Peradeniya, Peradeniya 20400, Sri Lanka \\ ${ }^{2}$ The Postgraduate Institute of Science, University of Peradeniya, Peradeniya 20400, Sri Lanka \\ ${ }^{3}$ Department of Veterinary Pathobiology, Faculty of Veterinary Medicine \& Animal Science, University of Peradeniya, \\ Peradeniya 20400, Sri Lanka
}

Received:26/04/2018; Accepted:02/08/2018

\begin{abstract}
Spinose ear tick, Otobius megnini (Family Argasidae) is a one-host soft tick that parasitizes domesticated animals and occasionally humans. It causes otoacariasis or parasitic otitis in humans and animals and also known to carry infectious agents. Intra aural infestations of $O$. megnini is a serious health problem in the well-groomed race horses in Nuwara Eliya. Otobius megnini collected from the ear canal of stabled horses in Nuwara Eliya racecourse were tested for three possible infections, Rickettsia, Theileria and Babesia. Genomic DNA was extracted from 22 ticks collected from 11 horses and then pathogen-specific DNA was amplified using PCR. Ticks from two horses (one thoroughbred and one stallion) tested PCR positive for Babesia but not for other infections. None of the horses however, showed any clinical symptoms of babesiosis. This is the first record of Babesia infections in O. megnini. However, the presence of Babesia DNA in O. megnini doesn't qualify it as the vector of equine babesiosis, horse blood has to be tested for the presence of parasite DNA or antibodies.
\end{abstract}

Keywords: Spinose ear tick, Babesiosis, Horses, Otoacariasis, Rickettsia, Theileria.

\section{INTRODUCTION}

The spinose ear tick, Otobius megnini (Dugès 1883) (Acari: Ixodida: Argasidae) is an economically important soft tick, parasitizes livestock mostly cattle, goats, sheep, and horses and infests humans as well (Naudé et al., 2001; Keirans and Pound, 2003; Ariyarante et al., 2016). It is a one-host tick from the New World with a wide geographical distribution and its original centre of distribution is considered to be the southwestern North America, from where it spread to Central and South America and then to the rest of the world (Estrada-Pena et al., 1999; Keirans and Pound, 2003). Since the larva and the nymph of this tick feed inside the ear canal of the host for a long period, it allows the tick to be distributed over a vast geographic region transcontinentally through the distribution of the host animals. Otobius megnini is thought to have reached India in mid1930s together with cattle or horses brought from Southern Africa. This tick species is recorded in race horses brought from farms in northern India for an auction at the Madras
Race Club (Joseph, 1982). There is a speculation that $O$. megnini was introduced to Sri Lanka from India via horse trading. The first report of $O$. megnini in Sri Lanka is in 2010 from stable workers and jockeys as an intra-aural infestation (Ariyaratne et al., 2010). In Sri Lanka, O. megnini appears to have a limited distribution with no records of it infesting any other domesticated animals other than horses in the racecourses (Diyes and Rajakaruna, 2016).

Otobius megnini is the causative agent of horse otoacariasis or parasitic otitis. This condition can cause serious injuries and occasionally death in horses (Wall and Shearer, 2008). The common clinical signs include abnormal head carriage, head shaking and head rubbing (Perris, 1995). Early studies report nervous disease (Ramanujachari and Alwar, 1955) and auricular nerve paralysis (FAO, 1958) due to the presence of $O$. megnini in the ear canal of horses. However, there is no conclusive evidence to support the classification of $O$. megnini as a paralysis tick. The fact that this tick feeds within the ears of its hosts where inflammatory reactions could affect the balance of the host and lead to symptoms that could be interpreted as being neurological in origin should be considered. Intermittent painful muscle cramps were described in horses that were severely infested with $O$. megnini (Madigan et al., 1995). Between muscle cramps, horses appear to be normal and once the ticks are removed clinical signs are reduced and recovered within 12 to $36 \mathrm{hrs}$ (Madigan et al., 1995). Recently, from Northern Mexico a two-year-old quarter breed was reported having myotonia and colic associated with the infestation of O. megnini (Zarate-Ramos et al., 2014).

Otobius megnini is known to carry some infectious agents. Coxiella burnetii, the causative agent of $\mathrm{Q}$ fever was recovered from $O$. megnini collected from dairy cattle in Southern California (Jellison et al., 1948). Nymphs of $O$. megnini were reported infecting two patients with Spotted fever group rickettsioses from Mexico (Bustamante et al., 1946). Studies have shown that $O$. megnini can be naturally infected with Ehrlichia canis but does not transmit the 
agent (Ewing et al., 1990). A study carried out in South Africa reported Borrelia burgdorferi seropositive cases of three horse riders and owner of a stable, 71 horses and five dogs but the $O$. megnini specimens collected from these hosts were negative for the infection (Fivaz et al., 1991).

Equine piroplasmosis and rickettsial infections are common among horses but there are no records of these infections in horses in Sri Lanka. However, human pathogenic Orientia tsutsugamushi, Rickettsia typhi and Rickttsia conorii (Kularatne et al., 2003; Kularatne et al., 2013), Theilaria orientalis, Theilaria annulata (among water buffaloes) (Sivakumar et al., 2012), Babesia bovis, Babesia bigemina (among cattle), Babesia gibsoni and Babesia canis (among dogs) have been reported (Sivakumar et al., 2012) in Sri Lanka. However, little is known about their prevalence, distribution and the vector-tick species. Hence, the present study examined the presence of three common tick-borne pathogens: Rickettsia, Theileria and Babesia in O. megnini infesting stabled horses in Nuwara Eliya.

\section{MATERIALS AND METHODS}

Ticks were collected from the ear canals of 11 thoroughbred horses in Nuwara Eliya racecourses during 2014 using small pieces of white open wove cotton bandages (new, cleaned bandage for every removal). The ticks together with earwax were placed in $100 \mathrm{ml}$ plastic vials and brought to the laboratory. From each horse, two fully engorged nymphs were cleaned and preserved in absolute ethanol and were kept at $-20{ }^{\circ} \mathrm{C}$. A total of 22 samples were used to analyze from 11 horses for the presence of Rickettsia, Theileria and Babesia infections in the tick.

\section{Molecular analysis}

Each nymph was washed in a series of ethanol (70\%, 50\%, $30 \%, 10 \%$ ) keeping 1 hour in each solution and were finally transferred into distilled water for 1 hour. Genomic DNA was extracted using QIAGEN DNeasy Blood and Tissue kit (Cat no: 69504, German) according to manufacturer's instructions. Eluted DNA was kept at $-20{ }^{\circ} \mathrm{C}$ until the PCR amplification. The PCR reactions for the detection of pathogenic DNA from ticks were performed with $5 \mu \mathrm{l}$ of extracted DNA, $1.5 \mu \mathrm{l}$ of each primer $(10 \mathrm{mM}), 5 \mu \mathrm{l}$ of $5 \mathrm{x}$ PCR buffer, $3 \mu \mathrm{l}$ of $\mathrm{MgCl}_{2}(25 \mathrm{mM}), 2 \mu \mathrm{l}$ of dNTPs $(2 \mathrm{mM})$, $0.25 \mu 1$ Taq DNA polymerase and $6.75 \mu \mathrm{l}$ DEPC water in a final reaction volume of $25 \mu \mathrm{l}$. After amplification, the PCR products were visualized by gel electrophoresis $(1.5 \%$ W/V) with a DNA molecular weight marker (GelPilot 100 bp Plus DNA Ladder, product no. 239045, QIAGEN).

\section{Detection of Rickettsia}

DNA extracts were screened for $190 \mathrm{kDa}$ protein antigen (ompA) gene using a nested PCR assay. Outer primers used for the PCR assays were $\operatorname{Rr} 190-70$ with gene sequence of, 5'-ATGGCGAATATTTCTCCAAAA-3' and $\mathrm{Rr}$ 190-701 with gene sequence of 5'-GTTCCGTTAATGGCAGCATCT-3' to amplify a $631 \mathrm{bp}$ segment. For the nested stage, $\mathrm{Rr} 190.70$ (5'-ATGGCGAATATTTCTCCAAAA-3') and $\mathrm{Rr}$ 190.602 (5'-AGTGCAGCATTCGCTCCCCCT-3') inner primers were used to amplify a 530-bp fragment of the Rickettsial ompA gene (Fournier et al., 1998; Santibáñez et al., 2013). A nested PCR was performed in $25 \mu$ volumes as stated above with the primers and $2 \mu$ of the first PCR product as the DNA template. The reaction mixtures were subjected to an initial denaturation step at $95{ }^{\circ} \mathrm{C}$ for $5 \mathrm{~min}$, followed by 42 repeated cycles at $95{ }^{\circ} \mathrm{C}$ for 40 seconds (denaturation), $57^{\circ} \mathrm{C}$ for 40 seconds (annealing), $68^{\circ} \mathrm{C}$ for 40 seconds (extension). Amplification was completed by a further $10 \mathrm{~min}$ step at $72^{\circ} \mathrm{C}$ (final extension). Same thermocycler parameters were used for the nested PCR with 30 cycles.

\section{Detection of Babesia}

Detection of Babesia isolates in DNA extracts were performed by amplifying a 284bp fragment of $18 \mathrm{~S}$ rRNA gene by using Bab $18 \mathrm{~S}$ forward primer 5'-TAG(AG) GATTGGAGGTCGTCA-3' and Bab $18 \mathrm{~S}$ reverse primer 5'-AACGGAATTAACCAGACAAA-3' (Hildebrandt et al., 2007). Thermal profile used for the amplification was 5 min initial denaturation at $94{ }^{\circ} \mathrm{C}$, followed by repeated 30 cycles of 30 seconds denaturation at $94{ }^{\circ} \mathrm{C}, 30$ seconds annealing at $50{ }^{\circ} \mathrm{C}, 30$ seconds extension at $72{ }^{\circ} \mathrm{C}$. The final extension was $2 \min$ at $72^{\circ} \mathrm{C}$.

\section{Detection of Theilaria}

Theileria genus-specific, forward primer 989F (5'-AGTTTCTGACCTATCAG-3') and reverse primer 990R (5'-TTGCCTTAAACTTCCTTG-3') were used to amplify a 1098-bp fragment of SSU rRNA gene (Durrani and Kamal, 2008). Amplification was done under the following thermocycler conditions: $95^{\circ} \mathrm{C}$ for $5 \mathrm{~min}$ (initial denaturation), followed by 30 cycles of denaturation, annealing and extension at $94{ }^{\circ} \mathrm{C}$ for 30 seconds; $55^{\circ} \mathrm{C}$ for 30 seconds, $72{ }^{\circ} \mathrm{C}$ for 45 seconds respectively. The final extension was at $72{ }^{\circ} \mathrm{C}$ for $7 \mathrm{~min}$.

\section{RESULTS AND DISCUSSION}

Analysis of 22 samples of $O$. megnini from 11 race horses for the presence of Rickettsia, Babesia and Theilaria infections revealed that only two ticks $(18.2 \%)$ collected from one thoroughbred and one stallion were PCR positive for Babesia infections. This study provides the first evidence of presence of Babesia in O. megnini. Although the DNA isolated from the tick was sent for sequencing to confirm the Babesia species, the results were not satisfactory. It is important to examine the horse blood for either parasite DNA or antibodies to confirm whether $O$. megnini acts as a vector for equine babesiosis. None of the horses however showed any symptoms of babesiosis. Recently, microscopic examination of blood samples from some of the horses in this stable has shown no positive results for Babesia or any other infection of blood parasites (Dissanayake et al., 2017). It could be possible that microscopy may have not picked the low parasitemia levels.

It is not clear the way in which $O$. megini became infected with the pathogen. Many of the race horses in Nuwara Eliya stables including the two horses with Babesia infected ticks were imported from India. Therefore, it can be suspected that infected ticks may have been introduced to Sri Lanka 
via horse trading. It is important that the horses undergo a proper and thorough quarantine process. Once the larvae attach to the horse ear canal, they feed, moult and come out as a fully engorged nymph. Adults are non-feeding, free living stage. Since, O. megnini is a one host tick and the adult females do not feed, spreading of infectious diseases from one host to another is limited unless the infectious agent shows both transovarial and transstadial transmission like Rickettsia bellii maintained in Ixodes loricatus (Horta et al., 2006).

Equine babesiosis (Equine piroplasmosis) is established in tropical, subtropical regions of the world and it is an important intra-erythrocytic protozoan that causes great economic loss to equine industry (De Waal, 1992). In Asia, equine babesiosis is frequently reported from India, China, Korea and Iran (Gautam and Dwivedi, 1976; Wise et al., 2013). So far, Babesia caballi and B. equi (some reported as Theileria equi but remains controversial) are frequently reported among horses and other equid species including donkeys, mules and zebras (Friedhoff and Soule, 1996). The information on soft ticks as vectors of these two Babesia species is scant. Recently, under laboratory conditions, Ornithodoros moubata has been identified as a suitable candidate to transmit B. equi (Battsetseg et al., 2007).

There was no indication of the presence of Rickettsia and Theilaria infections in $O$. megnini infesting the racehorses in Nuwara Eliya. The information on the distribution of Rickettsia spp. associating horses is limited. Besides, the relationship between soft ticks and Rickettsia spp. is poorly documented except for Carios capensis, Carios sawaii and Ornithodoros erraticus (Kawabata et al., 2006; Raoult and Parola, 2007). Although spotted fever group rickettsial infections have been recorded in hard ticks collected from some wild and domesticated animals in Sri Lanka, the list doesn't include horses (Liyanarachchi et al., 2015). Coxiella burnetii has been reported in some areas of Sri Lanka and has the capability of causing abortion, stillbirth and neonatal deaths in horses (Angelakis et al., 2012).

In Sri Lanka, O. megnini is reported only from horses in Nuwara Eliya racecourse. Dynamic nature of the life cycle and high population stability has enabled $O$. megnini to become an invasive tick in Nuwara Eliya racecourses (Diyes and Rajakaruna, 2016; 2017). Different strategies have been implemented to control the infestations of $O$. megnini in the stabled horses but none of them was successful. Recently, the use of flumethrin based acaricides (Diyes et al., 2016), parasitoid scuttle fly, Megaselia scalaris (Diyes et al., 2015) and predator ant species Tapinoma melanocephalum (Diyes et al., 2017) have shown to be effective in controlling the free-living stages of O. megnini. In Sri Lanka O. megnini is reported only from Nuwara Eliya racecourse. Though Babesia was found in O. megnini, it does not confirm its vector capacity. Presence of pathogenic nucleic acid in a tick only indicates the carrier status of the tick but not the interspecies transmission (Estrada-Peña and de la Fuente, 2014). Therefore, further studies are required to elucidate the vector capacity of $O$. menini for equine babesiosis and to confirm the species status. This tick has a high affinity to infest cattle posing a potential risk of spreading the infestation and associated tick-borne diseases into the nearby dairy farms.

\section{ACKNOWLEDGEMENT}

Authors thank the management of the racecourse in Nuwara Eliya, Kaushalya Karunathilake in the Department of Veterinary Pathobiology, Faculty of Veterinary Medicine \& Animal Science, University of Peradeniya, Rasika Alawatte, T.D.B. Lenadora, Punsiri Tennakoon and the National Research Council (Grant 11-44) for financial support.

\section{REFERENCES}

Angelakis, E., Munasinghe, A., Yaddehige, I., Liyanapathirana, V., Thevanesam, V., Bregliano, A., Socolovschi, C., Edouard, S., Fournier, P.E., Raoult, D. and Parola, P. (2012). Detection of rickettsioses and Q fever in Sri Lanka. The American Journal of Tropical Medicine and Hygiene 86(4):711-712.

Ariyarathne, S., Apanaskevich, D.A., Amarasinghe, P.H. and Rajakaruna, R.S. (2016). Diversity and distribution of tick species (Acari: Ixodidae) associated with human otoacariasis and socio-ecological risk factors of tick infestations in Sri Lanka. Experimental and Applied Acarology 70(1):99-123.

Ariyarathne, S., Rajakaruna, R.S., Ekanayake, D.H., Dilrukshi, P.R.M.P., Balasooriya, P.S. and Amarasinghe, P.H. (2010). Occurrence and distribution of tick species associated with human otoacariasis in selected districts of Sri Lanka. Proceedings of the 15th Peradeniya University Research Sessions (PURSE) Kandy, Sri Lanka.

Battsetseg, B., Matsuo, T., Xuan, X., Boldbaatar, D., Chee, S.H., Umemiya, R., Sakaguchi, T., Hatta, T, Zhou, J., Verdida , A.R., Taylor, D. and Fujisaki, K. (2007). Babesia parasites develop and are transmitted by the non-vector soft tick Ornithodoros moubata (Acari: Argasidae). Parasitology 134(1):1-8.

Bustamante, M.E., Varela, G. and Ortiz Mariotte, C. (1946). Estudios de fiebre manchada en Mexico. Fiebre manchada en la laguna. Revista del Instituto de Salubridad y Enfermedades Tropicales 7:39-49.

De Waal, D.T. (1992). Equine piroplasmosis: a review. British Veterinary Journal 148(1):6-14.

Desjardins, I. Joulié, A., Pradier, S., Lecollinet, S., Beck, C., Vial, L., Dufour, P., Gasqui, P., Legrand, L., Edouard, S. and Sidi-Boumedine, K. (2018). Seroprevalence of horses to Coxiella burnetii in an Q fever endemic area. Veterinary microbiology 215:49-56.

Dissanayake, S., Rajapakse, R.P.V.J. and Rajakaruna, R.S. (2017). Gastrointestinal parasites of domesticated and feral horses (Equus caballus) in Sri Lanka. Ceylon Journal of Science 46:17-26.

Diyes, G.C.P. and Rajakaruna, R.S. (2016). Seasonal dynamics of spinose ear tick Otobius megnini associated with horse otoacariasis in Sri Lanka. Acta Tropica 159: 170-175. 
Diyes, G.C.P. and Rajakaruna, R.S. (2017). Life cycle of Spinose ear tick, Otobius megnini (Acari: Argasidae) infesting the race horses in Nuwara Eliya, Sri Lanka. Acta Tropica 166:164-176.

Diyes, G.C.P. Karunarathna, N.B., Silva, T.H.S.E., Karunaratne W.A.I.P. and Rajakaruna R.S. (2017). Ants as predators of the Spinose Ear Tick, Otobius megnini (Dugés) in Sri Lanka Acarologia 57(4):747-753.

Diyes, G.C.P., Bandara, K.M.U.J., Rajakaruna, R.S. and Karunaratne, S.H.P.P. (2016). Assessment of susceptibility of the Spinose ear tick Otobius megnini (Acari: Argasidae) to selected acaricides. Proceedings of Peradeniya University Research Sessions (iPURSE), Sri Lanka 20: Pp.300.

Diyes, G.C.P., Karunaratne, W.A.I.P., Tomberlin, J.K. and Rajakaruna, R.S. (2015). Case Study First record of Megaselia scalaris (Loew) (Diptera: Phoridae) infesting a spinose ear tick, Otobius megnini, colony in Sri Lanka. Tropical Biomedicine 32(4):791-795.

Durrani, A.Z. and Kamal, N. (2008). Identification of ticks and detection of blood protozoa in Friesian cattle by polymerase chain reaction test and estimation of blood parameters in district Kasur, Pakistan. Tropical animal health and production 40(6): 441-447.

Estrada-Peña, A. and de la Fuente, J. (2014). The ecology of ticks and epidemiology of tick-borne viral diseases. Antiviral research 108:104-128.

Estrada-Peña, A. and Jongejan, F. (1999). Ticks feeding on humans: a review of records on human-biting Ixodidae with special reference to pathogen transmission. Experimental and applied acarology 23(9):685-715.

Ewing, S.A., Harkness, J.R., Kocan, K.M., Barker, R. W., Fox, J.C., Tyler, R.D., Cowell, R.L. and Morton, R.B. (1990). Failure to transmit Ehrlichia canis (Rickettsiales: Ehrlichieae) with Otobius megnini (Acari: Argasidae). Journal of Medical Entomology 27: 803-806.

Fivaz, B.H., Botha, P. and Cairns, L.M. (1991). A putative outbreak of equine Lyme borreliosis in Natal. Journal of the South African Veterinary Association 61:128-129.

Food and Agriculture Organization (1958). First meeting of the joint FAO/OIE expert panel on tick borne diseases of livestock, London, England: 24-29.

Fournier, P.E., Dubourg, G., Raoult, D. (2014). Clinical detection and characterization of bacterial pathogens in the genomics era. Genome Medicine 6: 114.Fournier, P.E., Roux, V. and Raoult, D. (1998). Phylogenetic analysis of spotted fever group rickettsiae by study of the outer surface protein rOmpA. International Journal of Systematic Bacteriology 48:839-849.

Friedhoff, K.T. and Soule, C. (1996). An account on equine babesiosis. Revue scientifiqueet technique (International Office of Epizootics) 15(3):1191.

Gautam, O.P. and Dwivedi, S.K. (1976). Equine babesiosis: A severe outbreak in a stud farm at Hisar. Indian Veterinary Journal 53:546-551.

Hildebrandt, A., Hunfeld, K.P., Baier, M., Krumbholz, A., Sachse, S., Lorenzen, T., Kiehntopf, M., Fricke, H.J. and Straube, E. (2007). First confirmed autochthonous case of human Babesia microti infection in Europe. European Journal of Clinical Microbiology and Infectious Diseases 26(8):595-601.

Jellison, W.L., Bell, E.J., Huebner, R.J., Parker, R.R. and Welsh, H.H. (1948). Q fever studies in Southern California. IV. Occurrence of Coxiella burneti in the spinose ear tick, Otobius megnini. Public Health Reports 63:1483-1489.

Joseph, S.A. (1982). Studies on the ecology, zoophilic and anthropophilic habits of the argasid ticks of Tamil Nadu. Cheiron 11:266-269.

Kawabata, H., Ando, S., Kishimoto, T., Kurane, I., Takano, A., Nogami, S., Fujita, H., Tsurumi, M., Nakamura, N., Sato, F., Takahashi, M., Ushijima, Y., Fukunaga, M. and Watanabe, H. (2006). First Detection of Rickettsia in Soft-bodied Ticks Associated with Seabirds, Japan. Microbiology and Immunology 50(5):403-406.

Keirans, J.E. and Pound, J.W. (2003). An annotated bibliography of the spinose ear tick, Otobius megnini (Dugès, 1883) (Acari: Ixodida: Argasidae) 1883-2000. Systematic and Applied Acarology Special Publication 13:1-68.

Kularatne, S.A.M., Edirisingha, J.S., Gawarammana, I.B., Urakami,H., Chenchittikul, M. and Kaiho, I. (2003). Emerging rickettsial infections in Sri Lanka: the pattern in the hilly Central Province. Tropical Medicine and International Health 8(9):803-811.

Kularatne, S.A.M., Rajapakse, R.P.V.J., Wickramasinghe, W.M.R.S., Nanayakkara, D.M., Budagoda, S.S., Weerakoon, K.G.A.D., Edirisinghe, J.S. and Premaratna. R. (2013). Rickettsioses in the central hills of Sri Lanka: serological evidence of increasing burden of spotted fever group. International Journal of Infectious Diseases 17(11):988-992.

Liyanaarachchi, D.R., Rajakaruna, R.S. and Rajapakse, R.P.V.J. (2015). Spotted fever group rickettsia in ticks infesting humans, wild and domesticated animals of Sri Lanka: one health approach. Ceylon Journal of Science (Biological Sciences) 44(2):67-74

Madigan, J.E., Valberg, S.J., Ragle, C. and Moody J.L. (1995). Muscle spasms associated with ear tick (Otobius megnini) infestations in five horses. Journal of the American Veterinary Medical Association 207: 74-76.

Naudé, T.W., Heyne, H., van der Merwe, I.R. and Benic, M.J. (2001). Spinose ear tick, Otobius megnini (Dugès, 1884) as the cause of an incident of painful otitis externa in humans. Journal of the South African Veterinary Association 72:118-119.

Perris, E.E. (1995). Parasitic dermatoses that cause pruritus in horses. Veterinary Clinics of North America Equine Practice 11:11-28.

Ramanujachari, G. and Alwar, V.S. (1955). Notes of parasitological interest. Ceylon Veterinary Journal 3: 38-40.

Raoult, D. and Parola, P. (2007). Rickettsial diseases. New York: Informa Healthcare USA.

Santibáñez, S., Portillo, A., Santibáñez, P., Palomar, A.M. and Oteo, J.A. (2013). Usefulness of rickettsial PCR assays for the molecular diagnosis of human rickettsioses. Enfermedades Infecciosasy Microbiología Clínica 31(5):283-288. 
Sivakumar, T., Kothalawala, H., Abeyratne, S.A., Vimalakumar, S.C., Meewewa, A.S., Hadirampela, D.T., Puvirajan, T., Sukumar, S., Kuleswarakumar, K., Chandrasiri, A.D., Igarashi, I. and Yokoyama, N. (2012). A PCR-based survey of selected Babesia and Theileria parasites in cattle in Sri Lanka. Veterinary parasitology 190(1):263-267.

Tissot-Dupont H, Amadei, M.A., Nezri, M. and Raoult, D. (2004). Wind in November, Q fever in December. Emerging Infectious Diseases 10(7):1264 -1269 .

Wall, R.L. and Shearer, D. (2008). Veterinary ectoparasites: biology, pathology and control. John Wiley and Sons.

Wise, L.N., Kappmeyer, L.S., Mealey, R.H. and Knowles, D.P. (2013). Review of equine piroplasmosis. Journal of Veterinary Internal Medicine 27(6):1334-1346.

Zarate-Ramos, J.J., Garza, A.M.N., Avila, D.E.Z. and Tovar, L.E.R. (2014). Myotonia and Colic Associated with the Spinose Ear Tick, Otobius megnini, in a Horse in Northern Mexico Journal of Parasitology Research 9:16-20. 